\title{
The role of diatom resting spores in pelagic-benthic coupling in the Southern Ocean
}

\author{
Mathieu Rembauville $^{1}$, Stéphane Blain ${ }^{1}$, Clara Manno ${ }^{2}$, Geraint Tarling $^{2}$, Anu Thompson ${ }^{3}$, George Wolff ${ }^{3}$, and \\ Ian Salter ${ }^{1,4}$ \\ ${ }^{1}$ Sorbonne Universités, UPMC Univ. Paris 06, CNRS, Laboratoire d'Océanographie Microbienne (LOMIC), \\ Observatoire Océanologique, 66650 Banyuls-sur-mer, France \\ ${ }^{2}$ British Antarctic Survey, Natural Environmental Research Council, High Cross, Madingley Road, Cambridge, CB3 0ET, UK \\ ${ }^{3}$ School of Environmental Sciences, 4 Brownlow Street, University of Liverpool, Liverpool, L69 3GP, UK \\ ${ }^{4}$ Faroe Marine Research Institute, Box 3051, 110, Torshavn, Faroe Islands
}

Correspondence: Ian Salter (ian.salter@obs-banyuls.fr, ians@hav.fo)

Received: 5 October 2017 - Discussion started: 10 October 2017

Revised: 20 March 2018 - Accepted: 13 April 2018 - Published: 18 May 2018

\begin{abstract}
Natural iron fertilization downstream of Southern Ocean island plateaus supports large phytoplankton blooms and promotes carbon export from the mixed layer. In addition to sequestering atmospheric $\mathrm{CO}_{2}$, the biological carbon pump also supplies organic matter (OM) to deep-ocean ecosystems. Although the total flux of OM arriving at the seafloor sets the energy input to the system, the chemical nature of OM is also of significance. However, a quantitative framework linking ecological flux vectors to OM composition is currently lacking. In the present study we report the lipid composition of export fluxes collected by five moored sediment traps deployed in contrasting productivity regimes of Southern Ocean island systems (Kerguelen, Crozet and South Georgia) and compile them with quantitative data on diatom and faecal pellet fluxes. At the three naturally iron-fertilized sites, the relative contribution of labile lipids (mono- and polyunsaturated fatty acids, unsaturated fatty alcohols) is 2-4 times higher than at low productivity sites. There is a strong attenuation of labile components as a function of depth, irrespective of productivity. The three island systems also display regional characteristics in lipid export. An enrichment of zooplankton dietary sterols, such as $\mathrm{C}_{27} \Delta^{5}$, at South Georgia is consistent with high zooplankton and krill biomass in the region and the importance of faecal pellets to particulate organic carbon (POC) flux. There is a strong association of diatom resting spore fluxes that dominate productive flux regimes with energy-rich unsaturated fatty acids. At the Kerguelen Plateau we provide a
\end{abstract}

statistical framework to link seasonal variation in ecological flux vectors and lipid composition over a complete annual cycle. Our analyses demonstrate that ecological processes in the upper ocean, e.g. resting spore formation and grazing, not only impact the magnitude and stoichiometry of the Southern Ocean biological pump, but also regulate the composition of exported OM and the nature of pelagic-benthic coupling.

\section{Introduction}

The biological pump transfers organic carbon (OC) from photosynthetic production to the deep ocean (Volk and Hoffert, 1985) with important implications for the sequestration of atmospheric $\mathrm{CO}_{2}$ (Sarmiento et al., 1988; Kwon et al., 2009). Only a minor fraction of the carbon fixed in the sunlit ocean reaches the deep ocean and sediments (Martin et al., 1987; Honjo et al., 2008), but this carbon and energy supply is essential for the functioning of deep-sea benthic ecosystems (Billett et al., 1983, 2001; Ruhl and Smith, 2004; Ruhl et al., 2008) . Commonly referred to as pelagic-benthic coupling (Graf, 1989), the composition, lability and timing of organic matter (OM) flux arriving at the seafloor can exert a large influence on benthic communities (Billett et al., 2001; Galeron et al., 2001; Mincks et al., 2005; Smith et al., 2006; Wolff et al., 2011).

Understanding the factors influencing the functioning of the biological pump remains a central question in biogeo- 
chemical oceanography (Boyd and Newton, 1995; Rivkin et al., 1996; Boyd and Trull, 2007; Guidi et al., 2016). Many different approaches have been adopted to study the biological pump, including carbon budgets (Emerson et al., 1997; Emerson, 2014), mixed layer nutrient inventories (Eppley and Peterson, 1979; Sarmiento et al., 2004), radionuclide disequilibria (Buesseler et al., 1992; Savoye et al., 2006), optical methods (Guidi et al., 2016), neutrally buoyant (Buesseler et al., 2000; Salter et al., 2007) and moored sediment traps (Berger, 1971; Honjo, 1976). Although all of these methods have their caveats, sediment traps offer the distinct advantage of collecting and preserving sinking particles for subsequent biological and chemical analysis. Moored sediment traps allow the direct quantification of sinking protists including dinoflagellates (e.g. Harland and Pudsey, 1999), diatoms (e.g. Salter et al., 2012), coccolithophores (e.g. Ziveri et al., 2007), radiolarians (e.g. Takahashi and Honjo, 1991), silicoflagellates (Rigual-Hernández et al., 2010), foraminifera (Salter et al., 2014) and zooplankton faecal pellets (Wilson et al., 2008, 2013). Indirect approaches use biomarkers such as lipids and amino acids to identify the source (algal, zooplanktonic, bacterial) and diagenetic status (lability, degree of preservation) of the exported OM (Wakeham, 1982; Wakeham et al., 1980, 1984, 1997, 2009; Kiriakoulakis et al., 2001; Lee et al., 2009; Salter et al., 2010). Although it is generally well-acknowledged that ecological vectors of flux are linked to the geochemical composition, studies providing a coupled description of biological components and OM composition of export fluxes remain relatively scarce (e.g. Budge and Parrish, 1998).

Southern Ocean island plateaus such as Kerguelen (Blain et al., 2007), Crozet (Pollard et al., 2009) and South Georgia (Tarling et al., 2012) provide a natural source of iron to the iron-poor waters of the Antarctic Circumpolar Current (de Baar et al., 1990; Martin et al., 1990). Currents and the topography of the sea floor lead to enrichment of iron in waters adjacent to the islands which supports large diatom-dominated phytoplankton blooms (Armand et al., 2008; Korb et al., 2008; Quéguiner, 2013) that contrast with the high nutrient, low chlorophyll (HNLC, Minas et al., 1986) regime that generally prevails in Antarctic waters. Previous studies of Southern Ocean island plateaus have identified the significance of resting spore formation by neritic diatom species (Eucampia antarctica var. antarctica, Chaetoceros (Hyalochaete), Thalassiosira antarctica) in response to nutrient limitation in mid-summer (Salter et al., 2012; Rembauville et al., 2015, 2016a). The export of resting spores generally occurs during short and intense events but they can account for a significant fraction (40-60\%) of annual carbon flux out of the mixed layer at these naturally fertilized sites. This process contributes to the $\sim 2$-fold increase in annual carbon export when compared to the HNLC sites (Salter et al., 2012; Rembauville et al., 2015, 2017).

Despite the general importance of resting spore ecology for particulate organic carbon (POC) export from naturally iron-fertilized systems in the Southern Ocean, there are some notable differences in the nature of export fluxes from Crozet, Kerguelen and South Georgia. At Crozet, in the Polar Front Zone (PFZ), the abundance of foraminifers and pteropods leads to a high export ratio of inorganic carbon to organic carbon (1 mol : mol, Salter et al., 2014). At Kerguelen, south of the polar front in the Antarctic Zone (AAZ) the ratio of inorganic carbon to organic carbon is much lower $(0.07)$ and $\mathrm{CaCO}_{3}$ flux is mainly attributed to coccoliths (Rembauville et al., 2016b). At South Georgia (AAZ), the faecal pellet contribution to carbon export is higher $(\sim 60 \%$ in summerautumn; Manno et al., 2015) when compared to Kerguelen (34\% of annual POC flux; Rembauville et al., 2015). The strong gradients in productivity and ecosystem structure that characterize these island systems offer a valuable framework to address the link between biological and geochemical composition of particle export.

The impact of different carbon export vectors on the lability of the exported OM is necessary to understand the impact of upper ocean ecology for pelagic-benthic coupling (Ruhl and Smith, 2004; Ruhl et al., 2008). High biomass of meio-, micro- and macrofauna in abyssal sediments of the Southern Ocean (Brandt et al., 2007) suggests a transfer of OM originating from photosynthetic autotrophs down to the seafloor. This diversity and biomass is not geographically homogeneous, but rather constrained by upper ocean productivity levels (Wolff et al., 2011; Lins et al., 2015). In this context, the comparison of lipid biomarkers in export fluxes originating from different sites in the Southern Ocean may help to understand how ecological processes at the origin of export flux also shape the magnitude and lability of OM supply to deep-sea benthic communities.

This study compiles lipid biomarker data from five annual sediment trap deployments in the vicinity of Southern Ocean Island plateaus in order to (i) compare the composition of lipid biomarkers in export fluxes collected in sites of various productivity levels and across different depths, (ii) identify how ecological export vectors, in particular resting spores, shape the lability of POC fluxes over a complete annual cycle and (iii) derive the potential implications of ecological flux vectors for pelagic-benthic coupling.

\section{Material and methods}

\subsection{Trap deployments and sample processing}

We compile data from five long-term sediment trap deployments located in the vicinity of island plateaus in the Southern Ocean (Fig. 1, Table 1). Two sediment traps were located upstream of the islands in HNLC waters (M6 and P2 at Crozet and South Georgia respectively) and three were located in naturally iron-fertilized and productive waters characterized by enhanced phytoplankton biomass (A3, M5 and P3 at Kerguelen, Crozet and South Georgia respectively). 


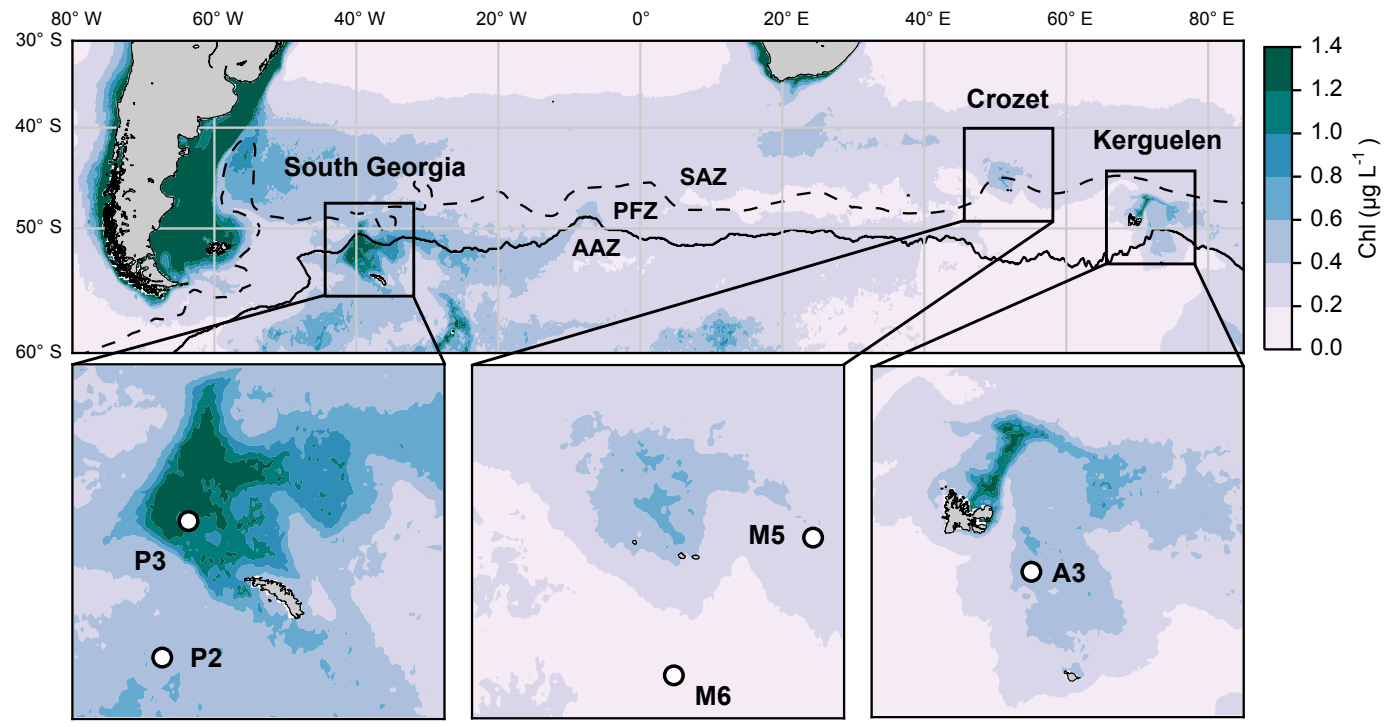

Figure 1. Location of the five annual sediment trap deployments in the Southern Ocean. Colours show annual surface satellite-derived chlorophyll $a$ climatology (MODIS 2002-2016 full mission product accessed at http://oceancolor.gsfc.nasa.gov/cms/, last access: 16 September 2014). Dashed and continuous lines represent respectively the Subantarctic Front (SAF) and polar front (PF) from Sallée et al. (2008). SAZ: Subantarctic Zone; PFZ: Polar Front Zone; AAZ: Antarctic Zone.

Table 1. Information on sediment trap deployments and fluxes of particulate organic carbon (POC) integrated over the deployment period.

\begin{tabular}{|c|c|c|c|}
\hline Location and reference & Trap model & Collection period & $\begin{array}{l}\text { Total POC flux } \\
\left(\mathrm{mmol} \mathrm{m}^{-2}\right)\end{array}$ \\
\hline \multicolumn{4}{|c|}{ Kerguelen (Rembauville et al., 2015) } \\
\hline A3 & Technicap & 21 Oct 2011-7 Sep 2012 & \multirow{3}{*}{98} \\
\hline $50^{\circ} 38.30^{\prime} \mathrm{S}, 72^{\circ} 02.60^{\prime} \mathrm{E}$ & PPS $3 / 3$ & No samples lost & \\
\hline $289 \mathrm{~m}$ & $0.125 \mathrm{~m}^{2}$ & Total: 322 days & \\
\hline \multicolumn{4}{|c|}{ South Georgia (Rembauville et al., 2016a) } \\
\hline P3 & \multirow{6}{*}{$\begin{array}{l}\text { McLane PARFLUX } \\
0.5 \mathrm{~m}^{2}\end{array}$} & 15 Jan 2012-1 Dec 2012 & \multirow{6}{*}{41} \\
\hline $52^{\circ} 43.40^{\prime} \mathrm{S}, 40^{\circ} 08.83^{\prime} \mathrm{W}$ & & One sample lost & \\
\hline $2000 \mathrm{~m}$ & & Total: 291 days & \\
\hline $\mathrm{P} 2$ & & 15 Jan 2012-1 Dec 2012 & \\
\hline $55^{\circ} 11.99^{\prime} \mathrm{S}, 41^{\circ} 07.42^{\prime} \mathrm{W}$ & & Three samples lost & \\
\hline $1500 \mathrm{~m}$ & & Total: 231 days & \\
\hline \multicolumn{4}{|l|}{ Crozet (Salter et al., 2012) } \\
\hline M5 & \multirow{6}{*}{$\begin{array}{l}\text { McLane PARFLUX } \\
0.5 \mathrm{~m}^{2}\end{array}$} & 28 Dec 2005-29 Dec 2005 & \multirow{3}{*}{40} \\
\hline $46^{\circ} 00.00^{\prime} \mathrm{S}, 56^{\circ} 05.00^{\prime} \mathrm{E}$ & & No samples lost & \\
\hline $3195 \mathrm{~m}$ & & Total 360 days & \\
\hline M6 & & 5 Jan 2005-3 Jan 2006 & \multirow{3}{*}{14} \\
\hline $49^{\circ} 00.03^{\prime} \mathrm{S}, 51^{\circ} 30.59^{\prime} \mathrm{E}$ & & No samples lost & \\
\hline $3160 \mathrm{~m}$ & & Total 359 days & \\
\hline
\end{tabular}

The detailed hydrological settings of deployments, preservative conditions of samples and bulk chemical analyses of biogeochemical fluxes have been published previously (Table 1). After the retrieval of each sediment trap, swimmers (organisms actively entering the trap funnel) were manually removed from the samples and therefore do not contribute to the lipid fluxes we report. 


\subsection{Lipid analysis}

Lipid analyses were performed on $1 / 8$ wet aliquots resulting from the splitting of original samples. Because of the low amount of material collected in some cups, $1 / 8$ wet aliquots were combined prior to the lipid analyses (Supplement). Some samples were lost upon recovery of sediment traps and two were contaminated with fish debris and therefore not included in lipid analyses. Full details of all sediment trap samples and those included in lipid analyses is provided in the Supplement (Tables S1-S5).

Lipids analyses of Crozet sediment trap samples were performed as described by Kiriakoulakis et al. (2001) and Wolff et al. (2011). For the Kerguelen and South Georgia samples a similar protocol was used. Briefly, separate $1 / 8$ aliquots were spiked with an internal standard $(5 \alpha(\mathrm{H})$-cholestane), sonicated (filters; $3 \times 15 \mathrm{~min}$; dichloromethane : methanol $9: 1$ ), transmethylated (methanolic acetyl chloride) and silylated (bis(trimethylsilyl)trifluoroacetamide; $1 \%$ trimethylsilane chloride; $\left.30-50 \mu \mathrm{L} ; 40^{\circ} \mathrm{C} ; 0.5-1 \mathrm{~h}\right)$. Gas chromatography - mass spectrometry (GC-MS) analyses were carried out using a GC Trace 1300 fitted with a split-splitless injector, using helium as a carrier gas $\left(2 \mathrm{~mL} \mathrm{~min}^{-1}\right)$ and column DB-5MS $(60 \mathrm{~m} \times 0.25 \mathrm{~mm}$ (i.d.), film thickness $0.1 \mu \mathrm{m}$, non-polar solution of $5 \%$ phenyl and $95 \%$ methyl silicone). The GC oven was programmed after $1 \mathrm{~min}$ from 60 to $170^{\circ} \mathrm{C}$ at $6^{\circ} \mathrm{C} \mathrm{min}{ }^{-1}$, then from 170 to $315^{\circ} \mathrm{C}$ at $2.5^{\circ} \mathrm{C} \mathrm{min}^{-1}$ and held at $315^{\circ} \mathrm{C}$ for $15 \mathrm{~min}$. The eluent from the GC was transferred directly to the electron impact source of a Thermoquest ISQMS single quadrupole mass spectrometer. Typical operating conditions were as follows: ionization potential, $70 \mathrm{eV}$; source temperature, $215^{\circ} \mathrm{C}$; trap current, $300 \mu \mathrm{A}$. Mass data were collected at a resolution of 600 , cycling every second from $50-600 \mathrm{Th}$ and were processed using Xcalibur software. Compounds were identified either by comparison of their mass spectra and relative retention indices with those available in the literature and/or by comparison with authentic standards. Quantitative data were calculated by comparison of peak areas of the internal standard with those of the compounds of interest, using the total ion current (TIC) chromatogram. The relative response factors of the analytes were determined individually for 36 representative fatty acids, sterols and alkenones using authentic standards. Response factors for analytes where standards were unavailable were assumed to be identical to those of available compounds of the same class.

\subsection{Statistical analyses}

The lipid composition of sediment trap samples from the five sites was investigated using principal component analysis (PCA) and the similarity of samples was studied using clustering (Ward aggregation criteria) based on lipid classes. This methodology has been used previously to study the organic geochemistry of sinking particles in the ocean (Xue et

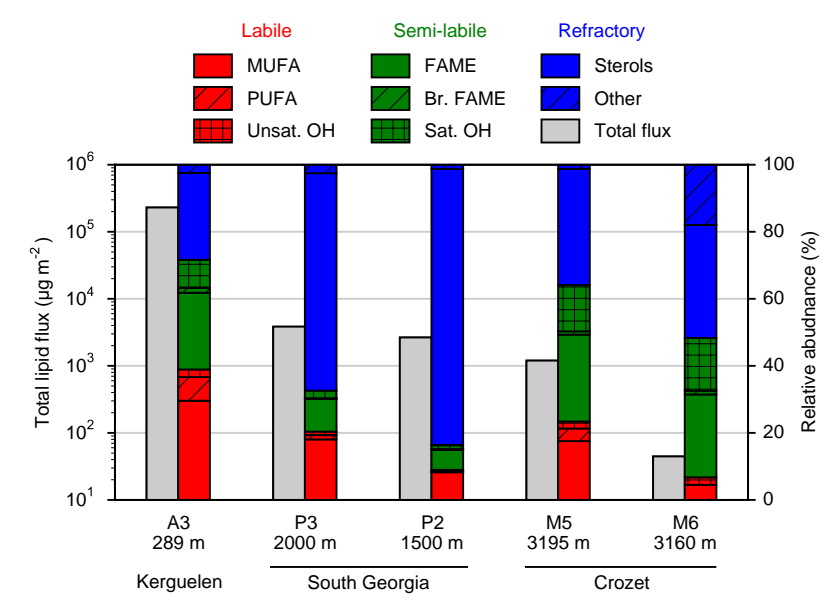

Figure 2. Total lipid fluxes (grey bars, left axis) integrated over the sediment trap deployment periods (Table 1) and the relative contribution of lipid classes (coloured bars, right axis) to this total flux from five moored sediment trap deployments in the Southern Ocean. Individual compound fluxes, concentrations and relative contributions are included in Supplement Tables S1-S5. A full list of the compounds categorized as others can also be found in the Supplement tables.

al., 2011). Prior to both PCA and clustering, raw lipid fluxes were transformed by calculating the square root of their relative abundance within each sample. This transformation followed by the calculation of the Euclidian distance is also known as the Hellinger distance, which provides a good compromise between linearity and resolution in ordination analyses (Legendre and Legendre, 1998; Legendre and Gallagher, 2001).

\section{Results}

\subsection{Lipid class distribution and seasonality}

Total lipid fluxes integrated over the sediment trap deployment period (Table 1) were 5 orders of magnitude higher in the shallow deployment at $\mathrm{A} 3\left(229 \mathrm{mg} \mathrm{m}^{-2}\right.$ at $\left.289 \mathrm{~m}\right)$ compared to the deep sediment trap at M6 $\left(0.08 \mathrm{mg} \mathrm{m}^{-2}\right.$ at $3160 \mathrm{~m}$, Fig. 2, Table 2). The contribution of labile lipid compounds (defined as unsaturated fatty acids and alkenols, (Wolff et al., 2011, Table 2) to total lipid fluxes was 2-4 times higher in the naturally fertilized sites (20-39\% at A3, $\mathrm{P} 3$ and M5) relative to the HNLC deployments $(<10 \%$ at P2 and M6; Table 2). Unsaturated fatty acids were dominated (> $80 \%$ ) by monounsaturated fatty acids (MUFA) at all sites. Semi-labile lipids (saturated fatty acids analysed as their methyl esters; FAMEs, branched fatty acids and alkanols (saturated alcohols); Table 2) accounted for a small fraction $(8-12 \%)$ of total lipids at South Georgia, but a higher fraction (40-46\%) at Crozet. Semi-labile lipids were dom- 
Table 2. Total annual lipid flux, relative contribution of lipid classes and lipid concentrations for the five sediment trap deployments. Labile - MUFA (monounsaturated fatty acids), PUFA (polyunsaturated fatty acids) and unsaturated alcohols; semi-labile - saturated fatty acids, branched fatty acids and saturated alcohols; refractory - sterols, other (Wolff et al., 2011). Sediment trap deployment periods are presented in Table 1. Individual compound fluxes, concentrations and relative contributions are included in Tables S1-S5 in the Supplement. A full list of the compounds categorized as others can also be found in the Supplement tables.

\begin{tabular}{|c|c|c|c|c|c|}
\hline Site & A3 & P3 & $\mathrm{P} 2$ & M5 & M6 \\
\hline Integrated lipid flux $\left(\mathrm{mg} \mathrm{m}^{-2}\right)$ & 228.8 & 3.83 & 2.67 & 1.20 & 0.08 \\
\hline \multicolumn{6}{|l|}{ Relative contribution (\%) } \\
\hline MUFA & 29.7 & 18.0 & 8.1 & 18.1 & 5.2 \\
\hline PUFA & 7.1 & 1.3 & 0.2 & 3.1 & 0.3 \\
\hline Unsaturated alcohols (alkenols) & 2.3 & 1.1 & 0.6 & 2.2 & 0.5 \\
\hline Saturated fatty acids & 23.0 & 9.7 & 5.9 & 26.0 & 30.5 \\
\hline Branched fatty acids & 1.4 & 0.2 & 0.3 & 1.3 & 0.8 \\
\hline Saturated alcohols (alkanols) & 8.5 & 2.3 & 1.7 & 13.2 & 14.5 \\
\hline Sterols & 26.0 & 64.8 & 81.9 & 34.6 & 35.0 \\
\hline Other & 2.0 & 2.5 & 1.3 & 1.5 & 13.3 \\
\hline Total lipid concentration (mg lipid $\mathrm{g} \mathrm{OC}^{-1}$ ) & 193.1 & 7.8 & 8.4 & 3.1 & 0.9 \\
\hline \multicolumn{6}{|l|}{ Lipid concentration $\left(\mu \mathrm{g}\right.$ lipid $\left.\mathrm{g} \mathrm{OC}^{-1}\right)$} \\
\hline MUFA & 57403.2 & 1397.6 & 687.6 & 565.8 & 49.1 \\
\hline PUFA & 13736.4 & 102.3 & 18.4 & 97.7 & 2.7 \\
\hline Unsaturated alcohols (alkenols) & 4403.6 & 82.5 & 47.7 & 68.2 & 5.1 \\
\hline Saturated fatty acids & 44359.3 & 755.2 & 497.5 & 810.7 & 289.0 \\
\hline Branched fatty acids & 2792.1 & 18.7 & 24.5 & 39.6 & 7.4 \\
\hline Saturated alcohols (alkanols) & 16325.6 & 176.2 & 145.2 & 411.7 & 137.0 \\
\hline Sterols & 50261.1 & 5021.9 & 6911.4 & 1077.7 & 331.6 \\
\hline Other & 3777.8 & 196.3 & 108.3 & 47.0 & 126.0 \\
\hline
\end{tabular}

inated by saturated fatty acid contributions at all sites (64$80 \%)$. Sterols were the dominant lipids at South Georgia $(65-82 \%)$ and were less abundant $(26-35 \%)$ at the other sites.

The total lipid concentration, expressed as total lipid flux normalized to organic carbon flux, decreased by 4 orders of magnitude between the shallowest (A3, 193.1 mg lipid $\mathrm{g} \mathrm{OC}^{-1}$ ) and the deepest (M6, $0.9 \mathrm{mg}$ lipid $\mathrm{g} \mathrm{OC}^{-1}$ ) deployment (Table 2). In the shallow deployment at Kerguelen (A3) high concentrations of MUFAs (57.4 mg lipid $\mathrm{g} \mathrm{OC}^{-1}$ ), PUFAs (13.7 mg lipid $\mathrm{g} \mathrm{OC}^{-1}$ ) and saturated fatty acids (44.4 mg lipid $\mathrm{g} \mathrm{OC}^{-1}$ ) were observed. All other deployments (P3, P2, M5 and M6) had much lower concentrations of labile and semi-labile compounds and were dominated by more refractory sterols $\left(0.3-6.9 \mathrm{mg}\right.$ lipid $\left.\mathrm{g} \mathrm{OC}^{-1}\right)$.

Samples from Crozet (M5 and M6) were positively projected on the first axis of the PCA together with saturated fatty acids, $\mathrm{C}_{28}-\mathrm{C}_{29}$ sterols and long-chain unsaturated fatty acids $\left(\mathrm{C}_{22}, \mathrm{C}_{24}\right.$; Fig. 3a). Samples from South Georgia (P3 and $\mathrm{P} 2$ ) were negatively projected on the first axis, close to $\mathrm{C}_{27}$ sterols. Samples from Kerguelen (A3) were positively projected on the second axis and mainly associated with $\mathrm{C}_{16^{-}}$ $\mathrm{C}_{20}$ unsaturated fatty acids.

Using the lipid composition, four main clusters of sediment trap samples could be identified based on the largest distance break after the first node of the dendrogram (Fig. 3b). Cluster A contained the majority of the spring and summer samples from the naturally fertilized sites of Kerguelen and Crozet (A3 and M5) characterized by the highest relative abundance of labile lipids (PUFA and MUFA). Cluster B was composed of summer and winter samples from A3 displaying a high abundance of alkenols. Cluster $\mathrm{C}$ contained spring and summer samples from the naturally fertilized site of South Georgia (P3) and several samples from Kerguelen and Crozet, and it was characterized by a mixture of labile, semi-labile and refractory lipids (MUFA, saturated fatty acids and sterols). Finally, cluster D was composed mostly of samples from the HNLC site of South Georgia (P2) and displayed a large dominance of sterols. 
(a)

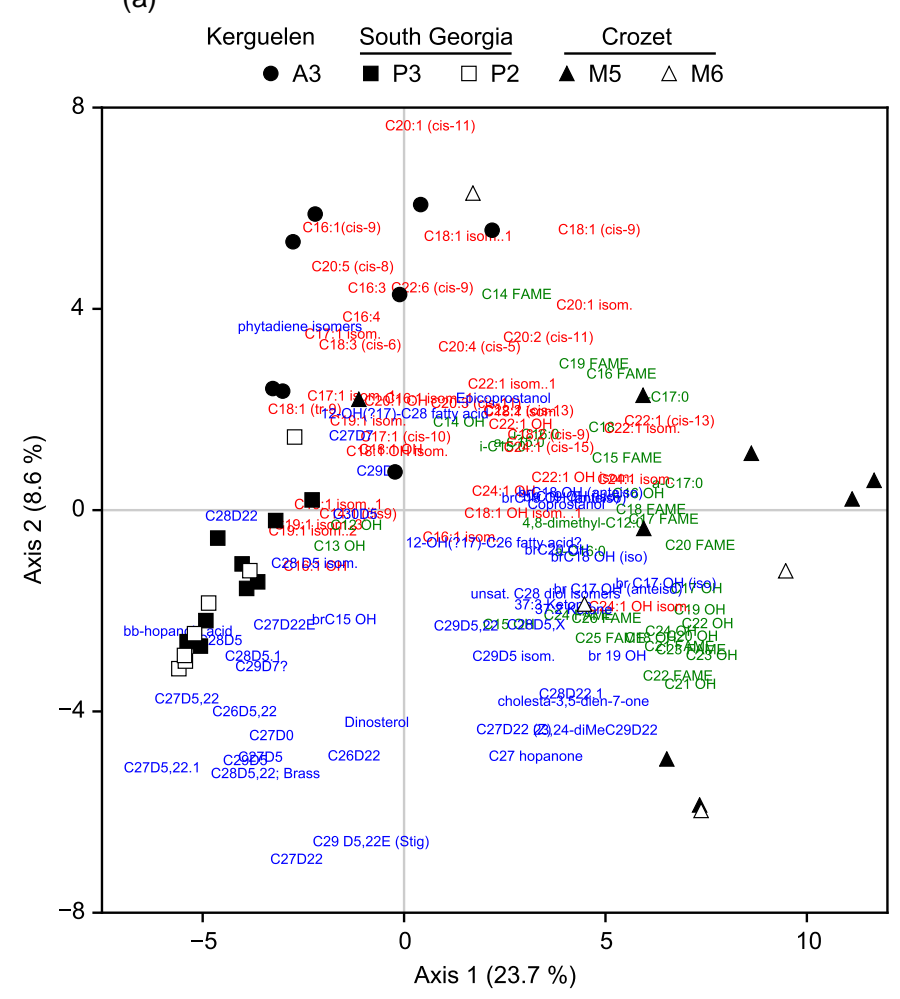

(b)
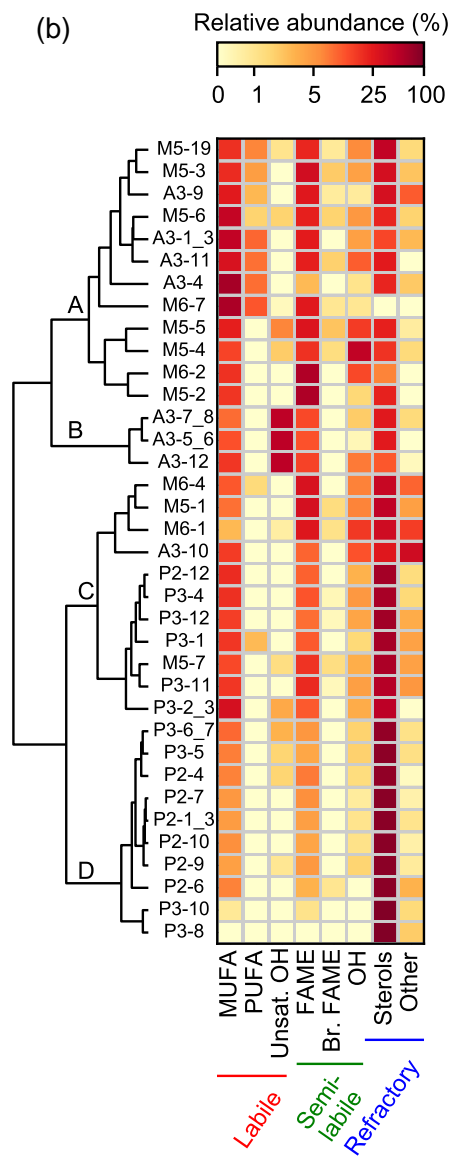

Figure 3. Association of lipid compounds with sediment trap samples. (a) Principal component analysis of the relative abundance of lipids $(n=121)$. Black and white symbols represent respectively the naturally fertilized and the low productivity sites. (b) Clustering of the sediment trap samples based on the relative abundance of lipid classes (Euclidian distance, Ward aggregation criteria). Clusters A, B, C and $\mathrm{D}$ were defined based on the highest distance break after the first node. In (a) and (b), colours show the lability of lipids according to Wolff et al. (2011).

\subsection{Seasonality at $\mathbf{A 3}$}

In spring, vegetative diatoms were the most important constituents of relatively low POC fluxes, followed by cylindrical faecal pellets (Fig. 4a). Lipid fluxes were dominated by 9Z-hexadecenoic acid ( $\mathrm{C}_{16: 1}$, cis-9; palmitoleic acid), hexadecanoic acid $\left(\mathrm{C}_{16}\right)$, eicosapentaenoic acid (EPA; $\mathrm{C}_{20: 5}$, cis-5,8,11,14,17), 9Z-octadecenoic acid $\left(\mathrm{C}_{18: 1}\right.$, cis-9) and cholesterol $\left(\mathrm{C}_{27} \Delta^{5}\right)$, which altogether contributed $>75 \%$ of total lipids (Fig. 4b).

Diatom resting spores dominated the enhanced POC fluxes during summer with a notable contribution of cylindrical and ovoid faecal pellets (Fig. 4c). MUFA and PUFA classes were the most significant components of lipid export. The principal compounds in these classes were $\mathrm{C}_{16: 1}$ (cis-9; $47 \%$ of total lipids), $\mathrm{C}_{18: 1}$ (cis-9; $10 \%$ ) and $\mathrm{C}_{20: 5}$ (cis-8; $5.3 \%$ ). Sterols accounted for $21 \%$ of total lipids and were primarily comprised of $\mathrm{C}_{27} \Delta^{5}$ (cholesterol) and $\mathrm{C}_{29} \Delta^{0}$ (Fig. $4 \mathrm{~d}$ ).
In autumn, tabular faecal pellets are the major vectors for POC flux (Fig. 4e), accompanied by a shift to more significant contributions of refractory sterols to the lipid composition, notably $\mathrm{C}_{27} \Delta^{5}$. The $\mathrm{C}_{16}$ fatty acid and $\mathrm{C}_{18: 1}$ (cis9), 11Z, 14Z, 17Z-eicosatrienoic acid $\left(\mathrm{C}_{20: 3}\right.$, cis-11) and $n$-hexadecanol $\left(\mathrm{C}_{16} \mathrm{OH}\right)$ were also important components of the lipid composition in autumn (Fig. 4f). During winter POC flux is mediated almost entirely by large faecal pellets (tabular and ellipsoid shapes) (Fig. 4g) and the unsaturated alcohols eicosenol $\left(\mathrm{C}_{20: 1} \mathrm{OH}\right)$ and octadecenol $\left(\mathrm{C}_{18: 1} \mathrm{OH}\right)$ were the major constituent of lipids, with smaller contributions from $\mathrm{C}_{16}$ fatty acids, $\mathrm{C}_{27} \Delta^{5}$ and $\mathrm{C}_{18: 1}$ (cis-9; Fig. 4h). 

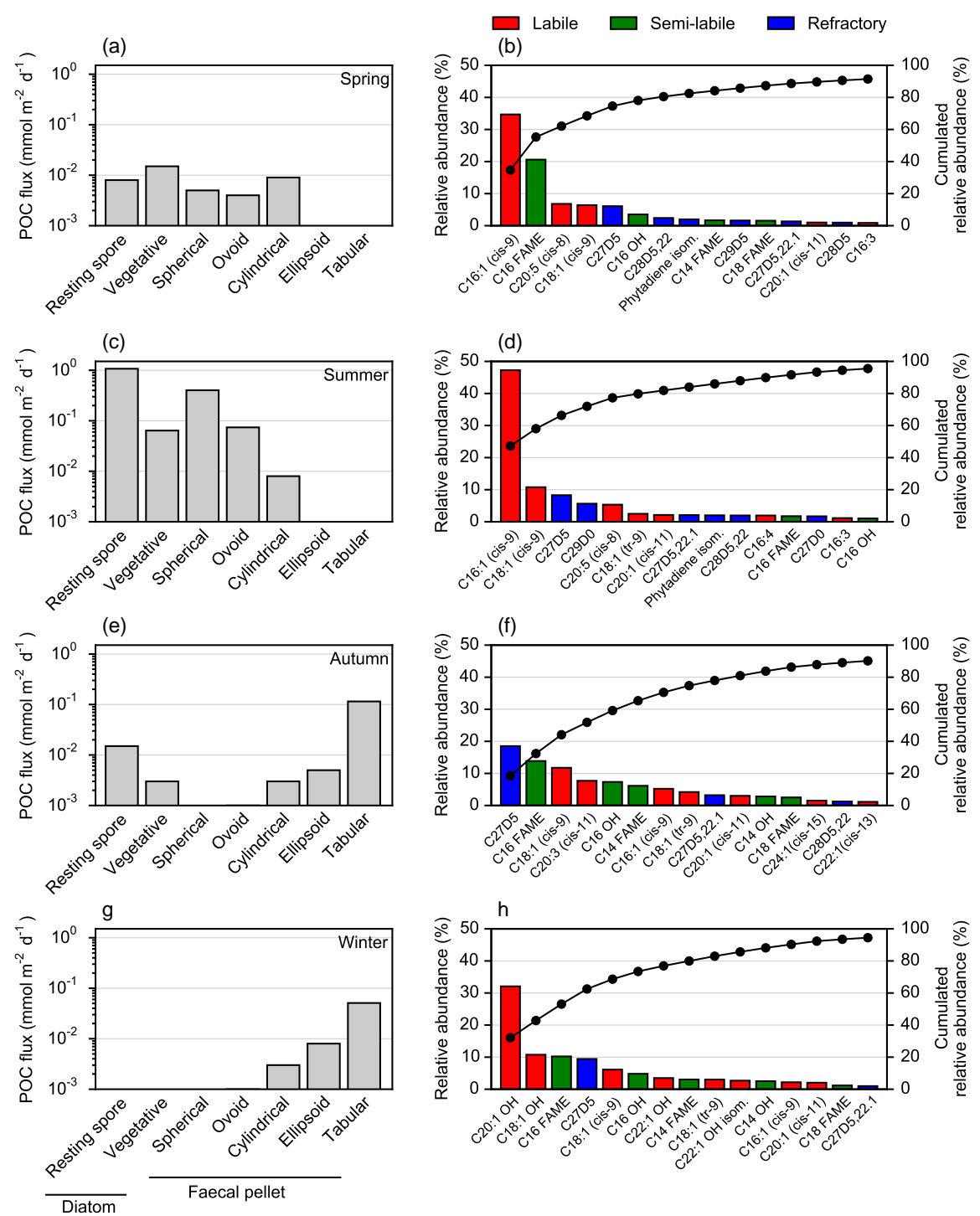

Figure 4. Seasonal evolution of carbon export vectors and associated lipid composition over the central Kerguelen Plateau (A3, 289 m). Left panels: carbon export vectors from Rembauville et al. (2015). Right panels: sorted relative abundance (coloured bars) and cumulated relative abundance (dots) of major lipids. (a) and (b) cups 1-3, (c) and (d) cup 9, (e) and (f) cup 11, (g) and (h) cup 12.

\section{Discussion}

\subsection{Geographical differences in lipid export composition across the Southern Ocean island systems}

Annual lipid export at the naturally fertilized sites of Crozet and South Georgia was characterized by relatively high fluxes of labile and semi-labile compounds compared to the HNLC sites. Similarly, at the iron-fertilized productive site on the Kerguelen Plateau, labile and semi-labile lipid classes dominate the annual flux profile. The labile lipid class was dominated by MUFAs, and to a lesser extent, PUFAs. In particular, two lipid compounds $\left(\mathrm{C}_{16: 1}, c i s-9\right.$; and EPA) com- monly associated with diatoms (Kates and Volcani, 1966; Lee et al., 1971) were important components of the labile lipid class. These observations confirm that the large diatomdominated phytoplankton blooms observed downstream of island plateaus (Armand et al., 2008; Korb et al., 2010; Quéguiner, 2013), which are supported by enhanced iron supply (Blain et al., 2008; Pollard et al., 2009; Nielsdóttir et al., 2012; Bowie et al., 2015), result in significant export of diatom-derived labile $\mathrm{OM}$ out of the mixed layer.

The PCA and clustering analyses reveal a notable degree of regional structure and highlight the prevalence of specific lipid classes in the different island systems. The first axis of the PCA ( $23.7 \%$ of variance) represents the location 
of the sediment trap deployments and the second axis corresponds to the deployment depth. The P3 and P2 sites at South Georgia both display $\sim 2$ times higher relative abundance of sterols compared to the Kerguelen (A3) and Crozet (M5 and M6) sites. Sterols are important components of the plasma membrane found in almost all eukaryotic organisms (Dufourc, 2008). Zooplankton use dietary sterols of phytoplankton origin, preferentially assimilating $\mathrm{C}_{27} \Delta^{5}$, or converting phytosterols to $\mathrm{C}_{27} \Delta^{5}$ (Volkman, 1986, 2003), which are ultimately egested in faecal pellets (Bradshaw and Eglinton, 1993; Prahl et al., 1984). An enrichment in $\mathrm{C}_{27} \Delta^{5}$ (and other $C_{27}$ sterols such as $C_{27} \Delta^{5,22}$ and $C_{27} \Delta^{22}$ ) in sinking $\mathrm{OM}$ is thus considered indicative of a high contribution of faecal material (Ternois et al., 1998) to export flux. The relative abundance of $\mathrm{C}_{27} \Delta^{5}, \mathrm{C}_{27} \Delta^{22}, \mathrm{C}_{27} \Delta^{5,22}$ compounds is highest in the export fluxes around South Georgia, consistent with the higher contribution of faecal pellets to carbon export at South Georgia (Manno et al., 2015) compared to Kerguelen (Rembauville et al., 2015). The biomass of zooplankton groups such as copepods and pteropods reach some of their highest Southern Ocean abundances in the northern Scotia Sea, which is also inhabited by Antarctic krill (Ward et al., 2012; Mackey et al., 2012).

\subsection{Depth-related trends in lipid composition}

The decrease in the total lipid flux of 5 orders of magnitude between the shallowest $(289 \mathrm{~m})$ and the deepest $(>3000 \mathrm{~m}$ ) deployment is consistent with the trend generally observed in the global ocean (Wakeham and Lee, 1993; Wakeham et al., 1997, 2009). Moreover, the strong decrease in OCnormalized lipid flux, particularly in the case of MUFA and PUFA compounds, suggests that these labile lipid classes are selectively remineralized during the sinking of the OM. It is possible that some of the differences observed over depth may be related to the initial lipid composition of organic material produced in the photic zone by different phytoplankton taxa. In the shallowest trap (A3, $289 \mathrm{~m}$ ), the high OCnormalized MUFA flux and the abundance of diatom-derived essential PUFAs $\left(\mathrm{C}_{16: 3}, \mathrm{C}_{18: 6}, \mathrm{C}_{20: 4}, \mathrm{C}_{20: 5}\right.$ and $\left.\mathrm{C}_{22: 6}\right)$ reflect the export of fresh and highly labile diatom-derived $\mathrm{OM}$ (Dunstan et al., 1993). By contrast, the presence of branched iso- and anteiso- $\mathrm{C}_{15}$ and $\mathrm{C}_{17}$ compounds in the deeper trap samples may be attributed to the activity of bacterial reworking of the particulate OM during settling (Kaneda, 1991; Wakeham et al., 1997).

\subsection{A quantitative framework linking seasonal variations in ecological flux vectors to particulate lipid composition}

In order to advance our understanding of the role of ecosystem structure in driving the composition of particle export, quantitative datasets characterizing both the chemical and biological nature of fluxes are required. The dataset from the
Kerguelen Plateau was selected as a basis for constructing a quantitative framework linking dominant ecological flux vectors with the particulate lipid composition of exported particles. Kerguelen was selected as a case study as we have previously reported detailed quantitative partitioning of POC fluxes between diatom and faecal pellet fluxes that reveal major seasonal shifts in the importance of different ecological flux vectors (Rembauville et al., 2015). The trap at Kerguelen was deployed $100 \mathrm{~m}$ beneath the mixed layer, and is therefore also characterized by the highest concentrations and fluxes of lipids (Table 2), thus providing the best possible resolution to examine seasonal changes in lipid composition in relation to ecological flux vectors.

\subsubsection{Spring}

During spring on the Kerguelen Plateau the lipid flux is low $\left(0.3 \mathrm{mg} \mathrm{m}^{-2} \mathrm{~d}^{-1}\right)$, as is the corresponding POC flux $\left(\sim 0.15 \mathrm{mmol} \mathrm{m}^{-2} \mathrm{~d}^{-1}\right)$, which is mainly driven by vegetative diatoms belonging to the genera Fragilariopsis, Pseudonitzschia and Thalassionema, as well as small faecal pellets (Rembauville et al., 2015). Diatoms are known predominantly to accumulate unsaturated fatty acids such as $\mathrm{C}_{16: 1}$ (cis-9), EPA and $\mathrm{C}_{18: 1}$ (cis-9; Kates and Volcani, 1966; Opute, 1974; Chen, 2012; Levitan et al., 2014). Diatoms also produce saturated fatty acids, mainly the $\mathrm{C}_{16}$ homologue (Lee et al., 1971; Matsumoto et al., 2009; Liang et al., 2014). Thus, although the spring lipid flux is quite low, the major compounds $\left(\mathrm{C}_{16: 1}\right.$, cis-9; $\mathrm{C}_{16}$; EPA and $\mathrm{C}_{18: 1}$, cis-9) represent an export assemblage dominated by vegetative diatoms.

\subsubsection{Summer}

During summer POC fluxes are enhanced by an order of magnitude and are characterized by intense export of diatom resting spores (Chaetoceros (Hyalochaete) spp. and to a lesser extent Thalassiosira antarctica) that contribute $60 \%$ of the annual POC flux (Rembauville et al., 2015). This resting spore flux event is associated with the highest export of total lipids $\left(2.4 \mathrm{mg} \mathrm{m}^{-2} \mathrm{~d}^{-1}\right.$, Table S1 in the Supplement). The summer lipid profile is dominated by $\mathrm{C}_{16: 1}$ (cis-9) and $\mathrm{C}_{18: 1}$ (cis-9), with a marked contribution of EPA. Higher total lipid contents have been documented in resting spores of Chaetoceros (Hyalochaete) and Thalassiosira antarctica when compared to vegetative cells (Doucette and Fryxell, 1983; Kuwata et al., 1993). More specifically, our results are consistent with the 8- to 12-fold increase in the content of $\mathrm{C}_{16: 1}$ (cis-9) and $\mathrm{C}_{18: 1}$ (cis-9) in Chaetoceros pseudocurvisetus resting spores when compared to the vegetative stages (Kuwata et al., 1993). An increase in the cell content of EPA during the formation of resting spores has also been reported for Chaetoceros salsugineus (Zhukova and Aizdaicher, 2001).

Resting spore formation is an ecological strategy utilized by certain diatom species to persist in environments where 
unfavourable conditions (e.g. light or nutrient limitation) occur (Smetacek, 1985; French and Hargraves, 1985; McQuoid and Hobson, 1996). Lipids produce more energy per unit mass than polysaccharides and can be stored in concentrated forms by diatoms (Obata et al., 2013). The accumulation of energy-rich unsaturated fatty acids in the resting spore, associated with reduced metabolism (Oku and Kamatani, 1999), and sinking to deeper waters (Smetacek, 1985) act in concert to increase the survival rate of the cells. In order for this ecological strategy to work the cells must be reintroduced to the surface mixed layer during a period favourable for growth. Nevertheless, sediment trap studies from Southern Ocean island systems clearly document that a significant portion of the resting spores formed in the surface are exported out of the mixed layer and reach bathypelagic depths (Salter et al., 2012; Rembauville et al., 2015, 2016a). Consequently, the ecological survival strategy of resting spore formation in diatoms can mediate large fluxes of labile lipid compounds to the seafloor.

Cholesterol $\left(\mathrm{C}_{27} \Delta^{5}\right)$ was a significant component (>10\%) of particulate lipid composition throughout the year. However, it reached its highest contribution $(18 \%)$ in autumn when the contribution of faecal pellets to POC flux increased. Unlike many eukaryotes, crustaceans are incapable of de novo biosynthesis of sterols and show a simple sterol composition dominated by $\mathrm{C}_{27} \Delta^{5}$ (Goad, 1981; Baker and Kerr, 1993; Kanazawa, 2001). Its presence throughout the year may thus be explained by the continuous export of spherical, ovoid and cylindrical faecal pellets (Fig. 4) which are typically attributed to copepods, amphipods and euphausiids (Wilson et al., 2008, 2013). Notably we observed the presence of a $\mathrm{C}_{29} \Delta^{0}$ sterol during summer. $\mathrm{C}_{29}$ sterols are abundant in diatoms (Volkman, 2003), and can account for 60 and $80 \%$ of total lipids of Navicula sp. and Eucampia antarctica var. antarctica respectively (Rampen et al., 2010), both of which showed clear seasonality with a marked summer maximum (Rembauville et al., 2015).

\subsubsection{Winter}

In winter, the lowest lipid fluxes were recorded and, in contrast with other samples, were dominated by monounsaturated alkenols $\left(\mathrm{C}_{18: 1} \mathrm{OH}\right.$ and $\left.\mathrm{C}_{20: 1} \mathrm{OH}\right)$. These compounds are generally absent in phytoplankton lipids but are an abundant component in zooplankton wax ester (Lee et al., 1971), and are often utilized as a marker for zooplanktonderived OM (Wakeham et al., 1997). More specifically, salp faecal pellets (tabular shape) have been shown to contain important amounts of $\mathrm{C}_{18: 1} \mathrm{OH}$ and $\mathrm{C}_{20: 1} \mathrm{OH}$ (Matsueda et al., 1986). This is in good agreement with the dominance of tabular faecal pellets in the winter POC flux at Kerguelen. Tabular faecal material is present in the export flux during autumn but alkenols represent a minor constituent of the lipid flux. We expect that this difference is primarily related to the larger contribution of diatoms to export flux (as both single cells or present in faecal pellets), but it may also reflect changes in zooplankton lipid composition across the season (Lee et al., 2006). Wax esters are used as an energy reserve (Lee et al., 1970) but also contribute to adjust buoyancy in cold and deep waters in winter (Pond and Tarling, 2011). The abundance of wax ester-derived compounds reported in winter is also consistent with observations from neritic areas of the Kerguelen Islands (Mayzaud et al., 2011). Another indicator of a seasonal shift from a diatom- (spring) to a faecal pelletdominated export system (autumn and winter) is the absence of long-chain PUFAs in autumn and winter. It has been previously reported that this energy-rich compound is preferentially assimilated by zooplankton and is therefore typically absent in faecal pellets (Stübing et al., 2003).

\subsection{Implications for pelagic-benthic coupling}

Diatom-resting spores account for $60 \%$ of annual particulate organic carbon (POC) export at $300 \mathrm{~m}$ from the ironfertilized bloom on the Kerguelen plateau (Rembauville et al., 2015). Similar patterns are observed in deeper trap samples $(>2000 \mathrm{~m}$ ) from the productive regime at South Georgia (P3), where $42 \%$ of annual POC export can be attributed to resting spores (Rembauville et al., 2016a). At the productive Crozet site (M5), Eucampia antarctica winter growth stages dominate flux at $3000 \mathrm{~m}$ and are strongly correlated with total POC flux (Salter et al., 2012). These findings are in contrast to sediment trap diatom assemblages from the low productivity/HNLC sites upstream of Kerguelen, Crozet and South Georgia that contain much lower quantities of resting spores $(<5 \%)$ with a negligible contribution to POC (Salter et al., 2012; Rembauville et al., 2016a, 2017). A consistent feature of Southern Ocean island systems is that the flux of diatom resting spores, in particular those of Chaetoceros spp. and E. antarctica, are important vectors of POC transport to the bathypelagic (>1500 m). In the bathypelagic ocean $(>1500 \mathrm{~m})$, concentrations of MUFAs and PUFAs are 2-25 times higher in particulate flux originating from the productive regimes of these iron-fertilized systems (Table 1; Wolff et al., 2011). These data demonstrate that resting spore flux also mediates enhanced fluxes of freshly labile organic matter, in the form of unsaturated fatty acids, to the bathypelagic ocean.

The oxidation of unsaturated fatty acids (MUFA and PUFA) classes produces more energy than their saturated fatty acid counterparts (Levitan et al., 2014). An energy-rich food supply associated with the resting spore flux appears to have an important impact on benthic systems. For example, the decoupling of abundance between mega-faunal invertebrates and OM input at Crozet appears in part to be related to enhanced labile lipid and pigment fluxes supporting higher fecundity of the dominant mega-faunal invertebrate Peniagone crozeti (Wolff et al., 2011). At South Georgia, nematode biomass is 10 times higher in deep-sea sediments $(>3000 \mathrm{~m})$ underlying iron-fertilized productivity regimes 
(Lins et al., 2015) whilst OM input varies by considerably less (Rembauville et al., 2016a). Nematode fatty acid profiles are significantly enriched in $\mathrm{C}_{16: 1}$ (cis-9) and EPA, two major lipid compounds we have shown to be statistically associated with summer export events dominated by diatom resting spores. Resistance to grazing (Kuwata and Tsuda, 2005) and enhanced sinking velocities of resting spores compared to vegetative cells (McQuoid and Hobson, 1996) result in their effective transfer to the seafloor (Rembauville et al., 2016a), consistent with the fact they are a common feature of sediments underlying productive regimes (Crosta et al., 1997; Armand et al., 2008; Tsukazaki et al., 2013). The ecology of resting spore formation therefore acts as an efficient conduit for transferring energy-rich storage lipids to the sediment, and they may thus play a particularly important role in pelagic-benthic coupling.

Deep-sea ecosystems are strongly dependent on OM food supply originating from photosynthesis in the surface ocean (Billett et al., 1983, 2001; Ruhl and Smith, 2004; Ruhl et al., 2008). In the Southern Ocean, it has been demonstrated how the composition of the upper ocean plankton community, and their associated ecological strategies, can influence the biological carbon pump (Smetacek et al., 2004; Salter et al., 2012, 2014; Assmy et al., 2013; Rembauville et al., 2015). The present study reveals how changes in major ecological flux vectors, and in particular the process of diatom resting spore formation, can also influence pelagic-benthic coupling by moderating the supply of energy-rich storage lipids to deep-sea communities.

Data availability. All data are available in the Supplement.

Supplement. The supplement related to this article is available online at: https://doi.org/10.5194/bg-15-3071-2018-supplement.

Competing interests. The authors declare that they have no conflict of interest.

Acknowledgements. We would like to acknowledge LEFE-CYBER (Project EXPLAIN, PI: Ian Salter) and the British Antarctic Survey for financial support of the work. We also express our sincere gratitude to two anonymous reviewers whose detailed comments significantly improved the quality of the manuscript.

Edited by: Gerhard Herndl

Reviewed by: two anonymous referees

\section{References}

Armand, L. K., Cornet-Barthaux, V., Mosseri, J., and Quéguiner, B.: Late summer diatom biomass and community structure on and around the naturally iron-fertilised Kerguelen Plateau in the Southern Ocean, Deep-Sea Res. Pt. II, 55, 653-676, https://doi.org/10.1016/j.dsr2.2007.12.031, 2008.

Assmy, P., Smetacek, V., Montresor, M., Klaas, C., Henjes, J., Strass, V. H., Arrieta, J. M., Bathmann, U., Berg, G. M., Breitbarth, E., Cisewski, B., Friedrichs, L., Fuchs, N., Herndl, G. J., Jansen, S., Krägefsky, S., Latasa, M., Peeken, I., Röttgers, R., Scharek, R., Schüller, S. E., Steigenberger, S., Webb, A., and Wolf-Gladrow, D.: Thick-shelled, grazer-protected diatoms decouple ocean carbon and silicon cycles in the iron-limited Antarctic Circumpolar Current, P. Natl. Acad. Sci. USA, 110, 20633-20638, https://doi.org/10.1073/pnas.1309345110, 2013.

Baker, B. J. and Kerr, R. G.: Biosynthesis of marine sterols, in: Marine Natural Products - Diversity and Biosynthesis, edited by: Scheuer, P. P. J., Topics in Current Chemistry, Springer, Berlin Heidelberg, 1-31, 1993.

Berger, W. H.: Sedimentation of planktonic foraminifera, Mar. Geol., 11, 325-358, https://doi.org/10.1016/00253227(71)90035-1, 1971.

Billett, D. S. M., Lampitt, R. S., Rice, A. L., and Mantoura, R. F. C.: Seasonal sedimentation of phytoplankton to the deep-sea benthos, Nature, 302, 520-522, https://doi.org/10.1038/302520a0, 1983.

Billett, D. S. M., Bett, B. J., Rice, A. L., Thurston, M. H., Galéron, J., Sibuet, M., and Wolff, G. A.: Long-term change in the megabenthos of the Porcupine Abyssal Plain (NE Atlantic), High resolution temporal and spatial study of the benthic biology and geochemistry of a North-Eastern Atlantic abyssal locality (BENGAL), Prog. Oceanogr., 50, 325-348, https://doi.org/10.1016/S0079-6611(01)00060-X, 2001.

Blain, S., Quéguiner, B., Armand, L., Belviso, S., Bombled, B., Bopp, L., Bowie, A., Brunet, C., Brussaard, C., Carlotti, F., Christaki, U., Corbière, A., Durand, I., Ebersbach, F., Fuda, J.L., Garcia, N., Gerringa, L., Griffiths, B., Guigue, C., Guillerm, C., Jacquet, S., Jeandel, C., Laan, P., Lefèvre, D., Lo Monaco, C., Malits, A., Mosseri, J., Obernosterer, I., Park, Y.-H., Picheral, M., Pondaven, P., Remenyi, T., Sandroni, V., Sarthou, G., Savoye, N., Scouarnec, L., Souhaut, M., Thuiller, D., Timmermans, K., Trull, T., Uitz, J., van Beek, P., Veldhuis, M., Vincent, D., Viollier, E., Vong, L., and Wagener, T.: Effect of natural iron fertilization on carbon sequestration in the Southern Ocean, Nature, 446, 10701074, https://doi.org/10.1038/nature05700, 2007.

Blain, S., Sarthou, G., and Laan, P.: Distribution of dissolved iron during the natural iron-fertilization experiment KEOPS (Kerguelen Plateau, Southern Ocean), Deep-Sea Res. Pt. II, 55, 594-605, https://doi.org/10.1016/j.dsr2.2007.12.028, 2008.

Bowie, A. R., van der Merwe, P., Quéroué, F., Trull, T., Fourquez, M., Planchon, F., Sarthou, G., Chever, F., Townsend, A. T., Obernosterer, I., Sallëe, J.-B., and Blain, S.: Iron budgets for three distinct biogeochemical sites around the Kerguelen Archipelago (Southern Ocean) during the natural fertilisation study, KEOPS2, Biogeosciences, 12, 4421-4445, https://doi.org/10.5194/bg12-4421-2015, 2015.

Boyd, P. and Newton, P.: Evidence of the potential influence of planktonic community structure on the interannual variability of particulate organic carbon flux, Deep-Sea Res. Pt. II, 42, 619639, https://doi.org/10.1016/0967-0637(95)00017-Z, 1995.

Boyd, P. W. and Trull, T. W.: Understanding the export of biogenic particles in oceanic waters: Is there consensus?, Prog. Oceanogr., 
72, 276-312, https://doi.org/10.1016/j.pocean.2006.10.007, 2007.

Bradshaw, S. A. and Eglinton, G.: Marine Invertebrate Feeding and the Sedimentary Lipid Record, in: Organic Geochemistry, Topics in Geobiology, edited by: Engel, M. H. and Macko, S. A., Springer, USA, 225-235, 1993.

Brandt, A., Gooday, A. J., Brandão, S. N., Brix, S., Brökeland, W., Cedhagen, T., Choudhury, M., Cornelius, N., Danis, B., De Mesel, I., Diaz, R. J., Gillan, D. C., Ebbe, B., Howe, J. A., Janussen, D., Kaiser, S., Linse, K., Malyutina, M., Pawlowski, J., Raupach, M., and Vanreusel, A.: First insights into the biodiversity and biogeography of the Southern Ocean deep sea, Nature, 447, 307-311, https://doi.org/10.1038/nature05827, 2007.

Budge, S. M. and Parrish, C. C.: Lipid biogeochemistry of plankton, settling matter and sediments in Trinity Bay, Newfoundland. II. Fatty acids, Org. Geochem., 29, 1547-1559, https://doi.org/10.1016/S0146-6380(98)00177-6, 1998.

Buesseler, K., Bacon, M. P., Cochran, J. K., and Livingston, H. D.: Carbon and nitrogen export during the JGOFS North Atlantic bloom experiment estimated from ${ }^{234} \mathrm{Th}:{ }^{238} \mathrm{U}$ disequilibria, Deep-Sea Res. Pt. I, 39, 1115-1137, 1992.

Buesseler, K. O., Steinberg, D. K., Michaels, A. F., Johnson, R. J., Andrews, J. E., Valdes, J. R., and Price, J. F.: A comparison of the quantity and composition of material caught in a neutrally buoyant versus surface-tethered sediment trap, Deep-Sea Res. Pt. I, 47, 277-294, https://doi.org/10.1016/S0967-0637(99)00056-4, 2000.

Chen, Y.-C.: The biomass and total lipid content and composition of twelve species of marine diatoms cultured under various environments, Food Chem., 131, 211-219, https://doi.org/10.1016/j.foodchem.2011.08.062, 2012.

Crosta, X., Pichon, J.-J., and Labracherie, M.: Distribution of Chaetoceros resting spores in modern periAntarctic sediments, Mar. Micropaleontol., 29, 283-299, https://doi.org/10.1016/S0377-8398(96)00033-3, 1997.

de Baar, H. J. W., Buma, A. G. J., Nolting, R. F., Cadée, G. C., Jacques, G., and Tréguer, P.: On iron limitation of the Southern Ocean: experimental observations in the Weddell and Scotia Seas, Mar. Ecol. Prog. Ser., 65, 105-122, https://doi.org/10.3354/meps065105, 1990.

Doucette, G. J. and Fryxell, G. A.: Thalassiosira antarctica: vegetative and resting stage chemical composition of an ice-related marine diatom, Mar. Biol., 78, 1-6, https://doi.org/10.1007/BF00392964, 1983.

Dufourc, E. J.: Sterols and membrane dynamics, J. Chem. Biol., 1, 63-77, https://doi.org/10.1007/s12154-008-0010-6, 2008.

Dunstan, G. A., Volkman, J. K., Barrett, S. M., Leroi, J.-M., and Jeffrey, S. W.: Essential polyunsaturated fatty acids from 14 species of diatom (Bacillariophyceae), Phytochemistry, 35, 155161, https://doi.org/10.1016/S0031-9422(00)90525-9, 1993.

Emerson, S.: Annual net community production and the biological carbon flux in the ocean, Global Biogeochem. Cy., 28, 2013GB004680, https://doi.org/10.1002/2013GB004680, 2014.

Emerson, S., Quay, P., Karl, D., Winn, C., Tupas, L., and Landy, M.: Experimental determination of the organic carbon flux from open-ocean surface waters, Nature, 359, 951-954, https://doi.org/10.1038/40111, 1997.
Eppley, R. W. and Peterson, B. J.: Particulate organic matter flux and new production in the deep ocean, Nature, 282, 677-680, https://doi.org/10.1038/282677a0, 1979.

French, F. W. and Hargraves, P. E.: Spore Formation in the Life Cycles of the Diatoms Chaetoceros Diadema and Leptocylindrus Danicus, J. Phycol., 21, 477-483, https://doi.org/10.1111/j.00223646.1985.00477.x, 1985.

Galeron, J., Sibuet, M., Vanreusel, A., Mackenzie, K. L., Gooday, A. J., Dinet, A., and Wolff, G. A.: Temporal patterns among meiofauna and macrofauna taxa related to changes in sediment geochemistry at an abyssal NE Atlantic site, Prog. Oceanogr., 50, 303-324, 2001.

Goad, L. J.: Sterol biosynthesis and metabolism in marine invertebrates, Pure Appl. Chem., 53, 837-852, https://doi.org/10.1351/pac198153040837, 1981.

Graf, G.: Benthic-pelagic coupling in a deep-sea benthic community, Nature, 341, 437-439, 1989.

Guidi, L., Chaffron, S., Bittner, L., Eveillard, D., Larhlimi, A., Roux, S., Darzi, Y., Audic, S., Berline, L., Brum, J., Coelho, L. P., Espinoza, J. C. I., Malviya, S., Sunagawa, S., Dimier, C., Kandels-Lewis, S., Picheral, M., Poulain, J., Searson, S., Tara Oceans Consortium Coordinators, Stemmann, L., Not, F., Hingamp, P., Speich, S., Follows, M., Karp-Boss, L., Boss, E., Ogata, H., Pesant, S., Weissenbach, J., Wincker, P., Acinas, S. G., Bork, P., de Vargas, C., Iudicone, D., Sullivan, M. B., Raes, J., Karsenti, E., Bowler, C., and Gorsky, G.: Plankton networks driving carbon export in the oligotrophic ocean, Nature, published online first, https://doi.org/10.1038/nature16942, 2016.

Harland, R. and Pudsey, C. J.: Dinoflagellate cysts from sediment traps deployed in the Bellingshausen, Weddell and Scotia seas, Antarctica, Mar. Micropaleontol., 37, 77-99, https://doi.org/10.1016/S0377-8398(99)00016-X, 1999.

Honjo, S.: Coccoliths: Production, transportation and sedimentation, Mar. Micropaleontol., 1, 65-79, https://doi.org/10.1016/0377-8398(76)90005-0, 1976.

Honjo, S., Manganini, S. J., Krishfield, R. A., and Francois, R.: Particulate organic carbon fluxes to the ocean interior and factors controlling the biological pump: A synthesis of global sediment trap programs since 1983, Prog. Oceanogr., 76, 217-285, https://doi.org/10.1016/j.pocean.2007.11.003, 2008.

Kanazawa, A.: Sterols in marine invertebrates, Fish. Sci., 67, $997-$ 1007, https://doi.org/10.1046/j.1444-2906.2001.00354.x, 2001.

Kaneda, T.: Iso- and anteiso-fatty acids in bacteria: biosynthesis, function, and taxonomic significance, Microbiol. Rev., 55, 288302, 1991.

Kates, M. and Volcani, B. E.: Lipid components of diatoms, Biochim. Biophys. Acta BBA - Lipids Lipid Metab., 116, 264 278, https://doi.org/10.1016/0005-2760(66)90009-9, 1966.

Kiriakoulakis, K., Stutt, E., Rowland, S. J., Vangriesheim, A., Lampitt, R. S., and Wolff, G. A.: Controls on the organic chemical composition of settling particles in the Northeast Atlantic Ocean, Prog. Oceanogr., 50, 65-87, https://doi.org/10.1016/S0079-6611(01)00048-9, 2001.

Korb, R. E., Whitehouse, M. J., Atkinson, A., and Thorpe, S. E.: Magnitude and maintenance of the phytoplankton bloom at South Georgia: a naturally iron-replete environment, Mar. Ecol. Prog. Ser., 368, 75-91, https://doi.org/10.3354/meps07525, 2008. 
Korb, R. E., Whitehouse, M. J., Gordon, M., Ward, P., and Poulton, A. J.: Summer microplankton community structure across the Scotia Sea: implications for biological carbon export, Biogeosciences, 7, 343-356, https://doi.org/10.5194/bg-7-3432010, 2010.

Kuwata, A. and Tsuda, A.: Selection and viability after ingestion of vegetative cells, resting spores and resting cells of the marine diatom, Chaetoceros pseudocurvisetus, by two copepods, J. Exp. Mar. Biol. Ecol., 322, 143-151, https://doi.org/10.1016/j.jembe.2005.02.013, 2005.

Kuwata, A., Hama, T., and Takahashi, M.: Ecophysiological characterization of two life forms, resting spores and resting cells, of a marine planktonic diatom, Mar. Ecol. Prog. Ser., 102, 245-255, 1993.

Kwon, E. Y., Primeau, F., and Sarmiento, J. L.: The impact of remineralization depth on the air-sea carbon balance, Nat. Geosci., 2, 630-635, https://doi.org/10.1038/ngeo612, 2009.

Lee, R. F., Nevenzel, J. C., and Paffenhöfer, G.-A.: Wax Esters in Marine Copepods, Science, 167, 1510-1511, https://doi.org/10.1126/science.167.3924.1510, 1970.

Lee, R. F., Hirota, J., and Barnett, A. M.: Distribution and importance of wax esters in marine copepods and other zooplankton, Deep-Sea Res., 18, 1147-1165, https://doi.org/10.1016/00117471(71)90023-4, 1971.

Lee, R. F., Hagen, W., and Kattner, G.: Lipid storage in marine zooplankton, Mar. Ecol. Prog. Ser., 307, 273-306, https://doi.org/10.3354/meps307273, 2006.

Lee, C., Peterson, M. L., Wakeham, S. G., Armstrong, R. A., Cochran, J. K., Miquel, J. C., Fowler, S. W., Hirschberg, D., Beck, A., and Xue, J.: Particulate organic matter and ballast fluxes measured using time-series and settling velocity sediment traps in the northwestern Mediterranean Sea, Deep-Sea Res. Pt. II, 56, 1420-1436, https://doi.org/10.1016/j.dsr2.2008.11.029, 2009.

Legendre, P. and Gallagher, E. D.: Ecologically meaningful transformations for ordination of species data, Oecologia, 129, 271280, https://doi.org/10.1007/s004420100716, 2001.

Legendre, P. and Legendre, L.: Numerical Ecology, Édition: 2, Elsevier Science, Amsterdam, New York, 1998.

Levitan, O., Dinamarca, J., Hochman, G., and Falkowski, P. G.: Diatoms: a fossil fuel of the future, Trends Biotechnol., 32, 117124, https://doi.org/10.1016/j.tibtech.2014.01.004, 2014.

Liang, Y., Maeda, Y., Yoshino, T., Matsumoto, M., and Tanaka, T.: Profiling of fatty acid methyl esters from the oleaginous diatom Fistulifera sp. strain JPCC DA0580 under nutritionsufficient and -deficient conditions, J. Appl. Phycol., 26, 22952302, https://doi.org/10.1007/s10811-014-0265-y, 2014.

Lins, L., da Silva, M. C., Hauquier, F., Esteves, A. M., and Vanreusel, A.: Nematode community composition and feeding shaped by contrasting productivity regimes in the Southern Ocean, Prog. Oceanogr., 134, 356-369, https://doi.org/10.1016/j.pocean.2015.03.006, 2015.

Mackey, A. P., Atkinson, A., Hill, S. L., Ward, P., Cunningham, N. J., Johnston, N. M., and Murphy, E. J.: Antarctic macrozooplankton of the southwest Atlantic sector and Bellingshausen Sea: Baseline historical distributions (Discovery Investigations, 1928-1935) related to temperature and food, with projections for subsequent ocean warming, Deep-Sea Res. Pt. II, 59, 130-146, 2012.
Manno, C., Stowasser, G., Enderlein, P., Fielding, S., and Tarling, G. A.: The contribution of zooplankton faecal pellets to deep-carbon transport in the Scotia Sea (Southern Ocean), Biogeosciences, 12, 1955-1965, https://doi.org/10.5194/bg-12-1955-2015, 2015.

Martin, J. H., Knauer, G. A., Karl, D. M., and Broenkow, W. W.: VERTEX: carbon cycling in the northeast Pacific, Deep-Sea Res. Pt. I, 34, 267-285, https://doi.org/10.1016/0198-0149(87)900860, 1987.

Martin, J. H., Gordon, R. M., and Fitzwater, S. E.: Iron in Antarctic waters, Nature, 345, 156-158, https://doi.org/10.1038/345156a0, 1990.

Matsueda, H., Handa, N., Inoue, I., and Takano, H.: Ecological significance of salp fecal pellets collected by sediment traps in the eastern North Pacific, Mar. Biol., 91, 421-431, https://doi.org/10.1007/BF00428636, 1986.

Matsumoto, M., Sugiyama, H., Maeda, Y., Sato, R., Tanaka, T., and Matsunaga, T.: Marine Diatom, Navicula sp. Strain JPCC DA0580 and Marine Green Alga, Chlorella sp. Strain NKG400014 as Potential Sources for Biodiesel Production, Appl. Biochem. Biotechnol., 161, 483-490, https://doi.org/10.1007/s12010-009-8766-x, 2009.

Mayzaud, P., Lacombre, S., and Boutoute, M.: Seasonal and growth stage changes in lipid and fatty acid composition in the multigeneration copepod Drepanopus pectinatus from Iles Kerguelen, Antarct. Sci., 23, 3-17, https://doi.org/10.1017/S0954102010000519, 2011.

McQuoid, M. R. and Hobson, L. A.: Diatom Resting Stages, J. Phycol., 32, 889-902, https://doi.org/10.1111/j.00223646.1996.00889.x, 1996.

Minas, H. J., Minas, M., and Packard, T. T.: Productivity in upwelling areas deduced from hydrographic and chemical fields, Limnol. Oceanogr., 31, 1182-1206, https://doi.org/10.4319/lo.1986.31.6.1182, 1986.

Mincks, S. L., Smith, C. R., and DeMaster, D. J.: Persistence of labile organic matter and microbial biomass in Antarctic shelf sediments: evidence of a sediment 'food bank', Mar. Ecol. Prog. Ser., 300, 3-19, 2005.

Nielsdóttir, M. C., Bibby, T. S., Moore, C. M., Hinz, D. J., Sanders, R., Whitehouse, M., Korb, R., and Achterberg, E. P.: Seasonal and spatial dynamics of iron availability in the Scotia Sea, Mar. Chem., 130-131, 62-72, https://doi.org/10.1016/j.marchem.2011.12.004, 2012.

Obata, T., Fernie, A. R., and Nunes-Nesi, A.: The Central Carbon and Energy Metabolism of Marine Diatoms, Metabolites, 3, 325346, https://doi.org/10.3390/metabo3020325, 2013.

Oku, O. and Kamatani, A.: Resting spore formation and biochemical composition of the marine planktonic diatom Chaetoceros pseudocurvisetus in culture: ecological significance of decreased nucleotide content and activation of the xanthophyll cycle by resting spore formation, Mar. Biol., 135, 425-436, https://doi.org/10.1007/s002270050643, 1999.

Opute, F. K.: Lipid and Fatty-acid Composition of Diatoms, J. Exp. Bot., 25, 823-835, 1974.

Pollard, R. T., Salter, I., Sanders, R. J., Lucas, M. I., Moore, C. M., Mills, R. A., Statham, P. J., Allen, J. T., Baker, A. R., Bakker, D. C. E., Charette, M. A., Fielding, S., Fones, G. R., French, M., Hickman, A. E., Holland, R. J., Hughes, J. A., Jickells, T. D., Lampitt, R. S., Morris, P. J., Nédélec, F. H., Nielsdóttir, M., Planquette, H., Popova, E. E., Poulton, A. J., Read, J. F., Seeyave, S., 
Smith, T., Stinchcombe, M., Taylor, S., Thomalla, S., Venables, H. J., Williamson, R., and Zubkov, M. V.: Southern Ocean deepwater carbon export enhanced by natural iron fertilization, Nature, 457, 577-580, https://doi.org/10.1038/nature07716, 2009.

Pond, D. W. and Tarling, G. A.: Phase transitions of wax esters adjust buoyancy in diapausing Calanoides acutus, Limnol. Oceanogr., 56, 1310-1318, https://doi.org/10.4319/lo.2011.56.4.1310, 2011.

Prahl, F. G., Eglinton, G., Corner, E. D. S., and O'hara, S. C. M.: Copepod Fecal Pellets as a Source of Dihydrophytol in Marine Sediments, Science, 224, 1235-1237, https://doi.org/10.1126/science.224.4654.1235, 1984.

Quéguiner, B.: Iron fertilization and the structure of planktonic communities in high nutrient regions of the Southern Ocean, Deep-Sea Res. Pt. II, 90, 43-54, https://doi.org/10.1016/j.dsr2.2012.07.024, 2013.

Rampen, S. W., Abbas, B. A., Schouten, S., and Sinninghe Damste, J. S.: A comprehensive study of sterols in marine diatoms (Bacillariophyta): Implications for their use as tracers for diatom productivity, Limnol. Oceanogr., 55, 91-105, https://doi.org/10.4319/1o.2010.55.1.0091, 2010.

Rembauville, M., Blain, S., Armand, L., Quéguiner, B., and Salter, I.: Export fluxes in a naturally iron-fertilized area of the Southern Ocean - Part 2: Importance of diatom resting spores and faecal pellets for export, Biogeosciences, 12, 3171-3195, https://doi.org/10.5194/bg-12-3171-2015, 2015.

Rembauville, M., Manno, C., Tarling, G.A., Blain, S., and Salter, I.: Strong contribution of diatom resting spores to deepsea carbon transfer in naturally iron-fertilized waters downstream of South Georgia, Deep-Sea Res. Pt. I, 115, 22-35, https://doi.org/10.1016/j.dsr.2016.05.002, 2016a.

Rembauville, M., Meilland, J., Ziveri, P., Schiebel, R., Blain, S., and Salter, I.: Planktic foraminifer and coccolith contribution to carbonate export fluxes over the central Kerguelen Plateau, Deep-Sea Res. Pt. I, 111, 91-101, https://doi.org/10.1016/j.dsr.2016.02.017, 2016b.

Rembauville, M., Salter, I., Dehairs, F., Miquel, J. C., and Blain, S.: Annual particulate matter and diatom export in a high nutrient, low chlorophyll area of the Southern Ocean, Polar Biol., 41, 2540, https://doi.org/10.1007/s00300-017-2167-3, 2017.

Rigual-Hernández, A. S., Bárcena, M. A., Sierro, F. J., Flores, J. A., Hernández-Almeida, I., Sanchez-Vidal, A., Palanques, A., and Heussner, S.: Seasonal to interannual variability and geographic distribution of the silicoflagellate fluxes in the Western Mediterranean, Mar. Micropaleontol., 77, 46-57, https://doi.org/10.1016/j.marmicro.2010.07.003, 2010.

Rivkin, R. B., Legendre, L., Deibel, D., Tremblay, J.-É., Klein, B., Crocker, K., Roy, S., Silverberg, N., Lovejoy, C., Mesplé, F., Romero, N., Anderson, M. R., Matthews, P., Savenkoff, C., Vézina, A., Therriault, J.-C., Wesson, J., Bérubé, C., and Ingram, R. G.: Vertical Flux of Biogenic Carbon in the Ocean: Is There Food Web Control?, Science, 272, 1163-1166, https://doi.org/10.1126/science.272.5265.1163, 1996.

Ruhl, H. A. and Smith, K. L.: Shifts in Deep-Sea Community Structure Linked to Climate and Food Supply, Science, 305, 513-515, https://doi.org/10.1126/science.1099759, 2004.

Ruhl, H. A., Ellena, J. A., and Smith, K. L.: Connections between climate, food limitation, and carbon cycling in abyssal sedi- ment communities, P. Natl. Acad. Sci. USA, 105, 17006-17011, https://doi.org/10.1073/pnas.0803898105, 2008.

Sallée, J. B., Speer, K., and Morrow, R.: Southern Ocean Fronts and their variability to climate modes, J. Climate, 21, 3020-3039, 2008.

Salter, I., Lampitt, R.S., Sanders, R., Poulton, A., Kemp, A. E. S., Boorman, B., Saw, K., and Pearce, R.: Estimating carbon, silica and diatom export from a naturally fertilised phytoplankton bloom in the Southern Ocean using PELAGRA: A novel drifting sediment trap, Deep-Sea Res. Pt. II, 54, 2233-2259, https://doi.org/10.1016/j.dsr2.2007.06.008, 2007.

Salter, I., Kemp, A. E. S., Lampitt, R. S., and Gledhill, M.: The association between biogenic and inorganic minerals and the amino acid composition of settling particles, Limnol. Oceanogr., 55, 2207-2218, https://doi.org/10.4319/lo.2010.55.5.2207, 2010.

Salter, I., Kemp, A. E. S., Moore, C. M., Lampitt, R. S., Wolff, G. A., and Holtvoeth, J.: Diatom resting spore ecology drives enhanced carbon export from a naturally iron-fertilized bloom in the Southern Ocean, Glob. Biogeochem. Cy., 26, GB1014, https://doi.org/10.1029/2010GB003977, 2012.

Salter, I., Schiebel, R., Ziveri, P., Movellan, A., Lampitt, R., and Wolff, G. A.: Carbonate counter pump stimulated by natural iron fertilization in the Polar Frontal Zone, Nat. Geosci., 7, 885-889, https://doi.org/10.1038/ngeo2285, 2014.

Sarmiento, J. L., Toggweiler, J. R., Najjar, R., Webb, D. J., Jenkins, W. J., Wunsch, C., Elderfield, H., Whitfield, M., and Minster, J.-F.: Ocean Carbon-Cycle Dynamics and Atmospheric $p \mathrm{CO}_{2}$, Philos. T. R. Soc. Lond. Math. Phys. Eng. Sci., 325, 3-21, https://doi.org/10.1098/rsta.1988.0039, 1988.

Sarmiento, J. L., Gruber, N., Brzezinski, M. A., and Dunne, J. P.: High latitude controls of thermocline nutrients and low latitude biological productivity, Nature, 427, 56-60, https://doi.org/10.1038/nature02127, 2004.

Savoye, N., Benitez-Nelson, C., Burd, A. B., Cochran, J. K., Charette, M., Buesseler, K. O., Jackson, G. A., Roy-Barman, M., Schmidt, S., and Elskens, M.: 234-Th sorption and export models in the water column: A review, Mar. Chem., 100, 234-249, https://doi.org/10.1016/j.marchem.2005.10.014, 2006.

Smetacek, V., Assmy, P., and Henjes, J.: The role of grazing in structuring Southern Ocean pelagic ecosystems and biogeochemical cycles, Antarct. Sci., 16, 541-558, https://doi.org/10.1017/S0954102004002317, 2004.

Smetacek, V. S.: Role of sinking in diatom life-history cycles: ecological, evolutionary and geological significance, Mar. Biol., 84, 239-251, https://doi.org/10.1007/BF00392493, 1985.

Smith, C. R., Mincks, S., and DeMaster, D. J.: A synthesis of bentho-pelagic coupling on the Antarctic shelf: food banks, ecosystem inertia and global climate change, Deep-Sea Res. Pt. II, 53, 875-894, 2006.

Stübing, D., Hagen, W., and Schmidt, K.: On the use of lipid biomarkers in marine food web analyses: An experimental case study on the Antarctic krill, Euphausia superba, Limnol. Oceanogr., 48, 1685-1700, https://doi.org/10.4319/lo.2003.48.4.1685, 2003.

Takahashi, K. and Honjo, S.: Radiolaria: flux, ecology, and taxonomy in the Pacific and Atlantic, Ocean Biocoenosis Series, 3, 1991, https://doi.org/10.1575/1912/408, 1991.

Tarling, G. A., Ward, P., Atkinson, A., Collins, M. A., and Murphy, E. J.: DISCOVERY 2010: Spatial and temporal variability 
in a dynamic polar ecosystem, Deep-Sea Res. Pt. II, 59-60, 1-13, https://doi.org/10.1016/j.dsr2.2011.10.001, 2012.

Ternois, Y., Sicre, M.-A., Boireau, A., Beaufort, L., Miquel, J.-C., and Jeandel, C.: Hydrocarbons, sterols and alkenones in sinking particles in the Indian Ocean sector of the Southern Ocean, Org. Geochem., 28, 489-501, https://doi.org/10.1016/S01466380(98)00008-4, 1998.

Tsukazaki, C., Ishii, K.-I., Saito, R., Matsuno, K., Yamaguchi, A., and Imai, I.: Distribution of viable diatom resting stage cells in bottom sediments of the eastern Bering Sea shelf, Deep-Sea Res. Pt. II, 94, 22-30, https://doi.org/10.1016/j.dsr2.2013.03.020, 2013.

Volk, T. and Hoffert, M. I.: Ocean carbon pumps: Analysis of relative strengths and efficiencies in ocean-driven atmospheric CO2 changes, in: Geophysical Monograph Series, edited by: Sundquist, E. T. and Broecker, W. S., American Geophysical Union, Washington, D.C., 99-110, 1985.

Volkman, J. K.: A review of sterol markers for marine and terrigenous organic matter, Org. Geochem., 9, 83-99, https://doi.org/10.1016/0146-6380(86)90089-6, 1986.

Volkman, J. K.: Sterols in microorganisms, Appl. Microbiol. Biotechnol., 60, 495-506, https://doi.org/10.1007/s00253-0021172-8, 2003.

Wakeham, S. G.: Organic matter from a sediment trap experiment in the equatorial north Atlantic: wax esters, steryl esters, triacylglycerols and alkyldiacylglycerols, Geochim. Cosmochim. Acta, 46, 2239-2257, https://doi.org/10.1016/0016-7037(82)90198-3, 1982.

Wakeham, S. G. and Lee, C.: Production, Transport, and Alteration of Particulate Organic Matter in the Marine Water Column, in: Organic Geochemistry, Topics in Geobiology, edited by: Engel, M. H. and Macko, S. A., Springer, USA, 145-169, 1993.

Wakeham, S. G., Farrington, J. W., Gagosian, R. B., Lee, C., DeBaar, H., Nigrelli, G. E., Tripp, B. W., Smith, S. O., and Frew, N. M.: Organic matter fluxes from sediment traps in the equatorial Atlantic Ocean, Nature, 286, 798-800, https://doi.org/10.1038/286798a0, 1980.

Wakeham, S. G., Lee, C., Farrington, J. W., and Gagosian, R. B.: Biogeochemistry of particulate organic matter in the oceans: results from sediment trap experiments, Deep-Sea Res. Pt. I, 31, 509-528, https://doi.org/10.1016/0198-0149(84)90099-2, 1984.
Wakeham, S. G., Hedges, J. I., Lee, C., Peterson, M. L., and Hernes, P. J.: Compositions and transport of lipid biomarkers through the water column and surficial sediments of the equatorial Pacific Ocean, Deep-Sea Res. Pt. II, 44, 2131-2162, https://doi.org/10.1016/S0967-0645(97)00035-0, 1997.

Wakeham, S. G., Lee, C., Peterson, M. L., Liu, Z., Szlosek, J., Putnam, I. F., and Xue, J.: Organic biomarkers in the twilight zone - Time series and settling velocity sediment traps during MedFlux, Deep-Sea Res. Pt. II, 56, 1437-1453, https://doi.org/10.1016/j.dsr2.2008.11.030, 2009.

Ward, P., Atkinson, A., and Tarling, G.: Mesozooplankton community structure and variability in the Scotia Sea: a seasonal comparison, Deep-Sea Res. Pt. II, 59, 78-92, 2012.

Wilson, S. E., Steinberg, D. K., and Buesseler, K. O.: Changes in fecal pellet characteristics with depth as indicators of zooplankton repackaging of particles in the mesopelagic zone of the subtropical and subarctic North Pacific Ocean, Deep Sea Res. Pt. II, 55, 1636-1647, https://doi.org/10.1016/j.dsr2.2008.04.019, 2008.

Wilson, S. E., Ruhl, H. A., and Smith Jr., K. L.: Zooplankton fecal pellet flux in the abyssal northeast Pacific: A 15 year time-series study, Limnol. Oceanogr., 58, 881-892, https://doi.org/10.4319/lo.2013.58.3.0881, 2013.

Wolff, G. A., Billett, D. S. M., Bett, B. J., Holtvoeth, J., FitzGeorgeBalfour, T., Fisher, E. H., Cross, I., Shannon, R., Salter, I., Boorman, B., King, N. J., Jamieson, A., and Chaillan, F.: The Effects of Natural Iron Fertilisation on Deep-Sea Ecology: The Crozet Plateau, Southern Indian Ocean, PLoS ONE, 6, e20697, https://doi.org/10.1371/journal.pone.0020697, 2011.

Xue, J., Lee, C., Wakeham, S. G., and Armstrong, R. A.: Using principal components analysis (PCA) with cluster analysis to study the organic geochemistry of sinking particles in the ocean, Org. Geochem., 42, 356-367, https://doi.org/10.1016/j.orggeochem.2011.01.012, 2011.

Zhukova, N. V. and Aizdaicher, N. A.: Lipid and Fatty Acid Composition during Vegetative and Resting Stages of the Marine Diatom Chaetoceros salsugineus, Bot. Mar., 44, 287-293, https://doi.org/10.1515/BOT.2001.037, 2001.

Ziveri, P., de Bernardi, B., Baumann, K. H., Stoll, H. M., and Mortyn, P. G.: Sinking of coccolith carbonate and potential contribution to organic carbon ballasting in the deep ocean, Deep-Sea Res. Pt. II, 54, 659-675, https://doi.org/10.1016/j.dsr2.2007.01.006, 2007. 